\title{
OPEM
}

www.opem.org

Oriental Pharmacy and Experimental Medicine 2008 8(2), 187-191

DOI 10.3742/OPEM.2008.8.2.187

\section{Analgesic and antidiarrhoeal activities of Treama orientalis Linn. in mice}

\author{
Sarder Nasir Uddin ${ }^{1, *}$, Khan Mohammad Ahsan Uddin ${ }^{1}$ and Firoz Ahmed ${ }^{2}$ \\ ${ }^{1}$ Biotechnology and Genetic Engineering Discipline, Khulna University, Khulna-9208, Bangladesh; ${ }^{2}$ Pharmacy \\ Discipline, Khulna University, Khulna-9208, Bangladesh
}

Received for publication May 18, 2007; accepted October 16, 2007

\begin{abstract}
SUMMARY
Trema orientalis Linn. is commonly grown in many parts of Bangladesh. Its leaves have been used for analgesic and anti-diarrhoeal activity in traditional medicine. This study evaluates the potential analgesic and anti-diarrhoeal activity of methanol and aqueous extracts of leaves in experimental acetic acid induced writhing and castor oil induced diarrhoea in mice. The aqueous extract of leaves showed significant $(P<0.001)$ analgesic effect in acetic acid induced writhing in mice at a dose of $500 \mathrm{mg} / \mathrm{kg}$ body weight In castor oil induced antidiarrhoeal screening both extract increased latent period $(P<$ $0.025)$ and decrease the number of stool $(P<0.025)$ at the dose of $500 \mathrm{mg} / \mathrm{kg}$ body weight comparable with that of the standard drug loperamide. The results provide a support for the use of this plant in traditional medicine and suggest its further investigation.
\end{abstract}

Key words: Analgesic; Antidiarrhoea; Trema orientalis Linn.; Extract

\section{INTRODUCTION}

During the past decade, traditional systems of medicine have become increasingly important in view of their safety. Current estimates suggest that, in many developing countries, a large proportion of the population relies heavily on traditional practitioners and medicinal plants to meet primary health care needs. Although modern medicine may be available in these countries, herbal medicines (phytomedicines) have often maintained popularity for historical and cultural reasons. Concurrently, many people in developed countries have begun to turn to alternative or complementary therapies, including medicinal herbs.

\footnotetext{
${ }^{*}$ Correspondence: Sarder Nasir Uddin, Biotechnology and Genetic Engineering Discipline, Khulna University, Khulna-9208, Bangladesh. Fax: +88041731244; E-mail: nasir713@yahoo.com
}

Bangladesh possesses rich floristic wealth and diversified genetic resources of medicinal plants. It has a widely ranging tropical and the agro climatic conditions, which are conducive for introducing and domesticating new and exotic plant varieties. The use of the plants, plant extracts and pure compounds isolated from natural sources provided the foundation to modern pharmaceutical compounds.

T. orientalis (Bengali name- Jibon or Chikon) is a tree and belongs to the Ulmaceae family. The plant is distributed in almost all districts of Bangladesh and is used in traditional medicine by the rural people and possesses various interesting pharmacological activities. The root of the plant is used in the treatment of diarrhoea, asthma and passing of blood in urine; the bark is used as poultice in muscular pain; the roots, barks and leaves are used in epilepsy (Kirtikar and Basu, 1980). In African folk medicine, it is used in many diseases including dysentery, 
hypertension, etc (Iwe, 1993). Fruit, leaves, bark, stems, twigs and seeds are also used in traditional medicine. The leaves are used to treat coughs and sore throats and the bark is used to make cough syrups. Other reported uses include remedies for bronchitis, gonorrhoea, malaria, yellow fever, toothaches, and intestinal worms (Rulangaranga, 1991).

As part of our continuing efforts to study the chemical and pharmacological aspects of the medicinal plants of Bangladesh, T. orientalis was investigated Successive extraction of dried powdered Leaves of T. orientalis (Family-Ulmaceae) methanol and aqueous extracts and the effects of both extracts were investigated analgesic and antidiarrhoeal activities. Since there is a vast resource of $T$. Orientalis in Bangladesh, the present study will provide some valuable information about the pharmacological properties of this plant.

\section{MATERIALS AND METHODS}

\section{Plant materials}

Fresh leaves of $T$. orientalis were collected from Khulna University Campus in Bangladesh. The plant was identified by the experts of Bangladesh National Herbarium, Mirpur, Dhaka (Accession no. 31,285) and a voucher specimen was also deposited there. The fresh leaves were cleaned, dried and pulverized. About $400 \mathrm{~g}$ of powdered material was taken in a clean, flat bottomed glass container (4 1) and soaked in 1,300 $\mathrm{ml}$ of $80 \%$ of methanol. The container was sealed and kept for a period of 10 days with occasional shaking and stirring. Then it was filtered and concentrated by evaporation.

\section{Experimental animal}

Young Swiss-albino mice aged 4 - 5 weeks, average weight 20 - $25 \mathrm{~g}$ were used for the experiment. The mice were purchased from the animal Research Branch of the International Centre for Diarrhoeal Disease and Research, Bangladesh (ICDDR, B). They were kept in standard environmental condition for one week for adaptation after their purchase and fed ICDDR, B formulated rodent feed and water.

\section{Analgesic activity test}

Analgesic activity of both methanol and aqueous extract was tested by acetic acid induced writhing model in mice (Whittle, 1964). Eighty four mice of either sex were grouped in six ( $\mathrm{n}=14$ per group). Each group received a particular treatment i.e. group-I for control, group-II for positive control, test group-I for aqueous extract at the dose of 250 $\mathrm{mg} / \mathrm{kg}$, test group-II for aqueous extract at the dose of $500 \mathrm{mg} / \mathrm{kg}$, test group-III for methanol extract at the dose of $250 \mathrm{mg} / \mathrm{kg}$ and test group-IV for methanol extract at the dose of $500 \mathrm{mg} / \mathrm{kg}$. $1 \%$ tween- 80 solution in deionized water at the doses $10 \mathrm{ml} / \mathrm{kg}$ per oral was used as control and Diclofenac-Na was used at the doses of $25 \mathrm{mg} / \mathrm{kg}$ body weights per oral as a standard positive control. To prepare suspension of the test samples at required doses, the required amount of extract was triturated in unidirectional manner by the addition of small amount of tween-80. After proper mixing of extract and tweeen- 80 , the volume was adjusted with deionized water. The test consists of injecting $0.7 \%$ acetic acid solution intraperitoneally. Control and test sample was given orally $30 \mathrm{~min}$ prior to acetic acid injection. Each mouse of all groups was observed carefully to count the number of writhing that they had made in $15 \mathrm{~min}$. Incomplete writhing was taken as half-writhing, so two halfwrithing were taken as one full writhing.

\section{Antidiarrhoeal acitvity test}

Antidiarrhoeal activity was tested using the castor oil induced diarrhea in mice (Chatterjee, 1993). Experimental animals were randomly selected and divided into four groups ( $n=5$ per group). Each group received a particular treatment i.e. group-I for control, group-II for positive control, test group-I for aqueous extract and test group-II for methanol at the dose of $500 \mathrm{mg} / \mathrm{kg}$, Loperamid was used at the doses of $4 \mathrm{mg} / \mathrm{kg}$ body weight as a standard. 
Control vehicle and the extract were administered orally, $1 \mathrm{~h}$ prior to the oral administration of castor oil at dose of $0.5 \mathrm{ml}$ per mice. Individual animals of each group were placed in separate cages having adsorbent paper beneath and examined for the presence of diarrhea every hour in five hour study after castor oil administered. Number of stool or any fluid that stained the adsorbent paper was counted at each successive hour during the experiment. The latent period of each mouse also counted.

\section{Statistical analysis}

Student's $t$-test was used to determine a significant difference between the control groups and experimental groups for both the experiment.

\section{RESULTS}

The crude extract of aqueous and methanol extract of leaves of $T$. orientalis linn. was used for analgesic and antidiarrhoeal activity in mice at different doses.

Analgesic activity of aqueous and methanol extract of T. orientalis leaves was tested by acetic acid induced writhing in mice. The methanol extract showed $16.67 \%$ and $30.01 \%$ acetic acid induced writhing inhibition in mice at the doses of $250 \mathrm{mg} / \mathrm{kg}$ and $500 \mathrm{mg} / \mathrm{kg}$ body weight respectively. But the Aqueous extract showed $38.34 \%$ and $56.67 \%$ acetic acid induced writhing inhibition in mice at the doses of $250 \mathrm{mg} / \mathrm{kg}$ and $500 \mathrm{mg} / \mathrm{kg}$ body weight respectively. This was comparable to diclofenac sodium where the inhibition was $48.34 \%$ at the dose of $25 \mathrm{mg} / \mathrm{kg}$ body weight (Table 1).

In the study of antidiarrhoeal activity, aqueous and methanol extract at the dose of $500 \mathrm{mg} / \mathrm{kg}$ body weight was used as test group, $1 \%$ tween- 80 at the dose of $10 \mathrm{mg} / \mathrm{kg}$ body weight was used as control and loperamide at the dose $4 \mathrm{mg} / \mathrm{kg}$ body weight was used as standard. From the study, it showed that both aqueous and methanol extract increased the latent period as compared to control and standard. In Table 2, it was found that aqueous extract and methanol extract increased the latent period $1.456 \mathrm{~h}$ and $1.240 \mathrm{~h}$ respectively whereas control and standard increased the latent period $1.096 \mathrm{~h}$ and $1.284 \mathrm{~h}$ respectively. From the same doses we also showed that both the aqueous and methanol extract decreased the number of stool as

Table 1. Effect of Trema orientalis on acetic acid induced writhing in mice $(n=4)$

\begin{tabular}{lcc}
\hline Animal group/Treatment & $\begin{array}{c}\text { Number of Writhing } \\
(\% \text { writhing) }\end{array}$ & Inhibition (\%) \\
\hline Group I-Control 1\% Tween-80 solution in water, 10 ml/kg, p.o. & $30 \pm 1.07(100)$ & 00 \\
Group II- Positive control-Diclofenac Sodium $25 \mathrm{mg} / \mathrm{kg}$, p.o. & $15.5 \pm 0.64^{*}(51.66)$ & 48.34 \\
Test group I- Aqueous extract $250 \mathrm{mg} / \mathrm{kg}$, p.o. & $18.5 \pm 0.97^{*}(61.66)$ & 38.34 \\
Test group II- Aqueous extract $500 \mathrm{mg} / \mathrm{kg}$, p.o. & $13 \pm 0.70^{*}(43.33)$ & 56.67 \\
Test group III- Methanol extract $250 \mathrm{mg} / \mathrm{kg}$, p.o. & $25 \pm 1.29^{*}(83.33)$ & 16.67 \\
Test group IV- Methanol Extract $500 \mathrm{mg} / \mathrm{kg}$, p.o. & $21 \pm 1.13^{*}(69.99)$ & 30.01 \\
\hline
\end{tabular}

Values are expressed as mean \pm S.E.M. ${ }^{*}$ indicates $P<0.001$ vs control; \%: percentage; p.o.: per oral.

Table 2. Effect of T. orientalis on castor oil induced diarrhea in mice (Latent Period)

\begin{tabular}{lcc}
\hline Animal group/Treatment & Dose $(\mathrm{mg} / \mathrm{kg}$, per oral) & Latent Period $(\mathrm{h})$ \\
\hline group-I, Control (1\% tween-80) & 10 & $1.096 \pm 0.025$ \\
group-II, Standard (loperamide) & 4 & $1.284 \pm 0.053$ \\
group-III, Test group (Aqueous extract) & 500 & $1.456 \pm 0.029^{*}$ \\
group-IV (Methanol extract) & 500 & $1.240 \pm 0.058^{*}$ \\
\hline
\end{tabular}

Values are expressed as mean \pm S.E.M. $(\mathrm{n}=5)^{*} P<0.025$ vs control. 
Table 3. Effect of Trema orientalis on castor oil induced diarrhea in mice (number of stools)

\begin{tabular}{cccc}
\hline $\begin{array}{c}\text { Animal } \\
\text { group/ } \\
\text { Treatment }\end{array}$ & $\begin{array}{c}\text { Dose } \\
\text { (mg/kg, per } \\
\text { oral) }\end{array}$ & $\begin{array}{c}\text { Period of } \\
\text { study } \\
(\mathrm{h})\end{array}$ & $\begin{array}{c}\text { Total no. } \\
\text { of stool }\end{array}$ \\
\hline Control & & 1 & $7.8 \pm 0.73$ \\
(1\% tween-80) & 10 & 2 & $5.0 \pm 0.59$ \\
& & 4 & $4.0 \pm 0.63$ \\
& & 5 & $3.6 \pm 0.60$ \\
& & 1 & $7.2 \pm 0.48$ \\
\hline Standard & 4 & 2 & $4.6 \pm 0.67$ \\
(loperamide) & & 3 & $3.2 \pm 0.37$ \\
& & 4 & $1.28 \pm 0.48$ \\
Test group & & 5 & $0.6 \pm 0.40$ \\
(Aqueous & 500 & 1 & $6.6 \pm 0.6^{*}$ \\
extract) & & 2 & $3.8 \pm 0.73^{*}$ \\
& & 4 & $0.8 \pm 0.48^{*}$ \\
& & 5 & $0.8 \pm 0.48^{*}$ \\
Test group & & 1 & $6.2 \pm 0.2$ \\
(Methanol & 500 & 2 & $4.4 \pm 0.86^{*}$ \\
extract) & & 3 & $3.8 \pm 0.68$ \\
& & 4 & $1.2 \pm 0.37^{*}$ \\
\hline & & 5 & $0.6 \pm 0.39$ \\
\hline
\end{tabular}

Values are expressed as mean \pm S.E.M. $(\mathrm{n}=5)^{*} \mathrm{P}<0.025$ vs control.

compared to the control and standard (Table 3). During the first hour, the number of stool was 6.6 and 6.2 for aqueous and methanol extract respectively, but the same time it was 7.8 and 7.2 for control and standard (Table 3). The mean number of stools was $6.2,4.4,3.8,1.2$ and 0.6 at the $1^{\text {st }}$ to $5^{\text {th }}$ hour for aqueous extract and 6.6, 3.8, 0.8, 0.8 and 0.2 at the $1^{\text {st }}$ to $5^{\text {th }}$ hour for methanol extract respectively. The given data showed that the increase in period decreases the number of stools.

\section{DISCUSSION}

For the millions of rural populations in countries of the developing world, diarrhoeal diseases continue to be the major cause of morbidity and mortality, with an estimated 1 billion episodes of illness and some 5 million or more deaths in children under 5 years. In such populations, preparations from herbs and plants remain the most common forms of treatment for diarrhoeal disease.

Acetic acid induced writhing model represents pain sensation by triggering localized inflammatory response. Acetic acid, which is used to induce writhing, causes algesia by liberation of endogenous substances, which in turn excite the pain nerve endings (Taesotikul et al., 2003).

The acetic acid induced writhing demonstrates a noxious stimulation in mice. The test consists of injecting $0.7 \%$ acetic acid solution intraperitoneally and then observed the animal for specific contraction of body referred as 'writhing'. A comparison of writhing was made between positive control (Diclofenac-Na), control and test sample given orally $30 \mathrm{~min}$ prior to acetic acid injection. If the sample possesses analgesic activity, the animal that received the sample will give lower number of writhing than the control, i.e. the sample having analgesic activity will inhibit writhing.

From the study it was found that aqueous extract of leaves at the doses of $500 \mathrm{mg} / \mathrm{kg}$ exhibited highly significant $(P<0.001)$ inhibition of writhing reflex by $56.76 \%$ while the standard drug diclofenac $(25$ $\mathrm{mg} / \mathrm{kg}$ body weight) inhibition was found to be $48.34 \%$ (Table 1). So, it is concluded that the aqueous extract of T. orientalis possess strong analgesic action.

Antidiarrhoeal activity of the aqueous and methanol extract of $T$. orientalis was tested using the model of castor oil induced diarrhea in mice. Castor oil, which was used to induce diarrhea in mice, mixes with bile and pancreatic enzymes and liberates ricinoleic acid from the triglycerides upon oral administration. Most of the ricinoleic acid remains in the intestine and produces its anti absorptive effect. The ricinoleic acid thus liberated readily forms ricinoleic salts with sodium and potassium in the lumen of the intestine. The salt formed as such behaves like a soap or surfactant within gut and at the mucosal surface. Most agreed view is that ricinoleate salt stimulates the intestinal 
epithelial cell's adenyl cyclase (Racusen et al., 1979) or release prostaglandin (Beubler et al., 1979).

The results showed that both the extract increase the latent period and decrease the number of stools i.e. delayed the onset of diarrhoeal episode at the dose of $500 \mathrm{mg} / \mathrm{kg}$ body weight. If the sample possesses antidiarrhoeal activity, the animal that received the sample will give longer latent period than the control, i.e. the sample having antidiarrhoeal activity will increase the latent period and the number of stools will decrease.

However, in toxicity evaluation of plant extracts by brine shrimp lethality bioassay, aqueous extract did not show any cytotoxic effect on brine shrimp but methanol extract displayed toxicity. The methanol extract showed cytotoxicity $\mathrm{LC}_{50}=120 \mu \mathrm{g} / \mathrm{ml}$ and $\mathrm{LC}_{90}=200 \mu \mathrm{g} / \mathrm{ml}$. So, we have concluded that the tested aqueous extract sample may be a good source of analgesic and antidiarrhoeal medicine.

\section{CONCLUSION}

Bangladesh imports a large quantity of pharmaceutical raw materials including medicinal plants and semi processed plant products to produce drugs and medicines. This huge foreign exchange can be saved if the indigenous medicinal plants or their semi-processed products are utilized by the manufacturers to satisfy their needs. From the above experiment, it could be suggested that both aqueous and methanol extract of $T$. orientalis leaves posses significant analgesic and antidiarrhoeal activity in mice. So, further pharmacological and toxicological study is required to establish the therapeutic uses of the plant.

\section{REFERENCES}

Beubler E, Juan H. (1979) Effect of Ricinoleic acid and other Laxatives in net water flux and prostaglandin E release by the rat colon. J. Pharm. Pharmacol. 31, 681-685.

Chatterjee TK. (1993) Handbook of laboratory Mice and Rats. pp. 133-139.

Farnsworth NR, Soejarto DD. (1991) Global importance of medicinal plants. In: Akerele, O, Heywood V, Synge H. (Eds.) "The Conservation of Medicinal Plants", Cambridge University Press, Cambridge, 25-51.

Iwe M M. (1993) Hand Book of Medicinal Plants. CRC Publication. p. 251.

Kirtikar, KR. and Basu, BD. 1980. Indian Medicinal Plants. 2nd Ed, Vol. 1. p. 264.

Racusen LC, Binder HJ. (1979) Ricinoleic acid stimulation of active anion secretion in colonic mucosa of the rat. J. Clin. Invest. 63, 743-749.

Rulangaranga ZK. (1991) Conservation of medicinal and aromatic plants in Tanzania, proceedings of a workshop on priority species for tree planting and afforestation in Tanzania, Morogoro, Tanzania. May 14-18, 1990.

Taesotikul T, Panthong A, Kanjanapothi D, Verpoorte R, scheffer JJC. (2003) Anti-inflammatory, antipyretic and antinociceptive activities of Tabernaemontana pandacaqui Poir. J. Ethnopharmacol. 84, 31-35.

Whittle BA. (1964) The use of changes in capillary permeability in mice to distinguish between narcotic and non-narcotic analgesics. Br. J. Pharmacol. Chemother. 22, 246-253.

World Health Organization. (1994) The treatment and prevention of acute diarhoea, Practical Guidelines. WHO, Geneva. (2nd Ed) pp. 1-4. 